\title{
PENGARUH KEMAMPUAN PEDAGOGIK GURU DENGAN HASIL BELAJAR IPS
}

\author{
Wahyu Bagja Sulfemi ${ }^{1}$ Dede Supriyadi ${ }^{2}$ \\ STKIP Muhammadiyah Bogor \\ surel: wahyubagja@gmail.com
}

\begin{abstract}
Abstrak : Penelitian bertujuan ini adalah untuk mengetahui hubungan antara persepsi siswa tentang kemampuan pedagogik guru dengan hasil belajar mata pelajaran IPS kelas VIII di SMP Al-Amin Pamijahan Bogor dengan jumlah populasinya 153 siswa di ambil 25 persen yang berjumlah respondenya 60 siswa. Metode yang digunakan dalam penelitian ini adalah metode penelitian kuantitatif dengan menggunakan pendekatan korelasional. Penelitian kuantitatif adalah penelitian dengan memperoleh data kualitatif yang diangkakan. Metode korelasi yaitu penelitian yang melibatkan hubungan satu atau lebih dengan variabel lain. Bentuk hubungan dalam penelitian ini adalah brivaret, yaitu hubungan yang melibatkan satu variabel bebas dengan satu variabel terikat. Pengumpulan data dilakukan dengan menggunakan angket atau kusioner untuk memperoleh data variabel X yaitu persepsi siswa tentang kemampuan pegagogik guru dan metode pengambilan data dari nilai ujian Tengah semester ganjil untuk variabel Y yaitu hasil belajar. Adapun perolehan frekuensi untuk variabel X dengan skor tertinggi 93 dan skor terendah 32 diperoleh rata- rata 66,6, median 67,5 dan modus 68,49, sedangkan untuk variabel Y skor tertinggi 95 dan skor terendah 61 di peroleh rata-rata 80,25,median 89,5dan modus 86,75. Terdapat hubungan antara persepsi siswa tentang kemampuan pedagogik guru dengan hasil belajar mata pelajaran IPS kelas VIII di SMP Al-Amin Pamijahan Bogor. Hal ini dapat dibuktikan dengan derajat kebebasan $(\mathrm{dk})=\mathrm{N}-2$ dan $\mathrm{a}=0,025$ sebesar 2,000. $\mathrm{t}$ hitung $(5,38)>\mathrm{t}$ tabel $(2,000)$ maka koefsien korelasi adalah signifikan. Nilai $r$ hitung adalah 0,577 sedangkan $r$ tabel adalah 0,254 dengan batas signifikan 5 persen artinya nilai $r$ hitung lebih besar dari $r$ tabel yakni 0,577>0,254
\end{abstract}

\section{Kata kunci : Pedagogik Guru, Hasil Belajar, Mata Pelajaran IPS}

\begin{abstract}
The aim of this study is to find out the relationship between students' perceptions of teacher's pedagogic abilities and learning outcomes of social studies subjects in class VIII in Bogor Al-Amin Pamijahan Middle School with a population of 153 students taken 25 percent of which are 60 students. The method used in this study is a quantitative research method using a correlational approach. Quantitative research is research by obtaining qualitative data that is expected. Correlation method is research that involves the relationship of one or more with other variables. The form of the relationship in this research is brivaret, which is a relationship that involves one independent variable with one dependent variable. Data collection was done by using questionnaires or questionnaires to obtain $\mathrm{X}$ variable data, namely students' perceptions of teacher's pagagogic abilities and data collection methods from odd semester midterm test scores for $\mathrm{Y}$ variables, namely learning outcomes. The frequency gain for variable $X$ with the highest score of 93 and the lowest score of 32 obtained an average of 66.6, median 67.5 and mode 68.49, while for variable $Y$ the highest score was 95 and the lowest score 61 was obtained on average 80,25 , median 89.5 and mode 86.75 . There is a relationship between students' perceptions of pedagogic abilities of teachers with learning outcomes of social studies subjects in class VIII at Al-Amin Pamijahan Middle School, Bogor. This can be proven by degrees of freedom $(\mathrm{dk})=\mathrm{N}-2$ and a $=0.025$ of 2,000 . $t$ count $(5.38)>t$ table $(2,000)$ then the correlation coefficient is significant. The value of $r$ count is 0.577 while the $r$ table is 0.254 with a significant limit of 5 percent meaning that the value of $r$ count is greater than $\mathrm{r}$ table which is $0.577>0.254$.
\end{abstract}

Keywords: Teacher Pedagogics, Learning Outcomes, Social Studies Subjects

\section{PENDAHULUAN}

Ilmu Pengetahuan Sosial (IPS) merupakan salah satu mata pelajaran yang dipelajari oleh siswa tingkat Sekolah Menengah Pertama (SMP). Pelajaran Ilmu 
Pengetahuan Sosial (IPS) di SMP masih bersifat umum, yaitu gabungan antara geografi, sejarah, sosiologi, antropologi, ekonomi yang terpadu. Mata pelajaran IPS bertujuan mengembangkan potensi potensi peserta didik agar peka terhadap masalah sosial yang terjadi di masyarakat, memiliki sikap mental positif terhadap perbaikan segala ketimpangan yang terjadi, dan terampil mengawasi setiap masalah yang terjadi seharihari baik yang menimpa dirinya sendiri maupun yang menimpa kehidupan masyarakat, berbangsa dan bernegara.

Pembelajaran ilmu pengetahuan sangat perlu karena mata pelajaran IPS memuat kajian manusia dan lingkungan, sistem sosial dan budaya, prilaku ekonomi dan kesejahteraan serta waktu berkelanjutan dan perubahan. Melalui pembelajaran IPS peserta didik di arahkan, dibimbing, dan dibantu untuk menjadi warga negara Indonesia yang baik. Oleh karenanya pembelajaran IPS di rancang untuk membangun dan membina peerta didik dalam memasuki kehidupan bermasyrakat pada masa yang akan datang yang selalu berubah dan berkembang terus menerus.

Dalam dunia pendidikan, kemampuan atau kompetensi seorang guru sangatlah dituntut baik dalam pengamalan tugas-tugasnya ataupun dalam kehidupan sehariharinya. Dalam hal ini jika seorang tenaga pendidik atau guru telah mampu melakukan hal-hal itu maka masyarakat ataupun lingkungan sosial akan dengan sendirinya mengakui dan menerima keberadaan tenaga pendidik atau guru sebagai bagian dari lingkungan masyarakat itu sendiri. Untuk itu seorang guru atau tenaga pendidik dapat diterima oleh masyarakat, seorang tenaga pendidik atau guru hendaknya harus terlebih dahulu dapat diterima oleh dirinya sendiri, karena hal itu akan mempengaruhi totalitas serta loyalitas seorang guru tersebut sehingga seorang guru akan mampu mengeluarkan potensi serta kemampuannya secara maksimal.

Untuk itu penilaian terhadap kemampuan pedagogik guru berdasarkan tingkat pemenuhan harapan siswa tersebut dipandang sebagai persepsi siswa tentang kemampuan pembelajaran guru. Seorang guru yang ketat dan tegas terhadap siswanya akan mempengaruhi persepsi dari siswa terhadap guru, baik pengaruh positif maupum negatif. Pengaruh positif yang di timbulkan dari sikap guru tersebut, misalnya siswa akan lebih disiplin saat mengikuti pelajaran guru tersebut karena siswa mempunyai persepsi bahwa guru yang bersangkutan disiplin. Namun bila sikap ketat dan tegas itu di terapkan berlebihan maka akan menimbulkan persepsi siswa bahwa guru yang 
bersangkutan tidak bersahabat, akibatnya siswa menjadi tertekan dalam mengikuti pelajaran guru yang bersangkutan.

Berdasarkan Observasi dan wawancara dengan beberapa guru yang mengajar di SMP Al-Amin yang berada di Kecamatan Pamijahan, jumlah siswa/siswi yang ada dikelas VIII itu berjumlah 153 siswa dari 4 rombel, memang tidak terlalu banyak tetapi walaupun jumlahnya kalah dari sekolah-sekolah lain siswa itu selalu bersemangat dalam belajarnya dan gurunya memiliki sifat dan prilaku yang sama, para guru bersemangat dan penuh tanggung jawab dalam pembelajaran. Meskipun kondisi guru udah berlulusan S1 bahkan ada yang S2 di SMP Al-Amin yang berada di kecamatan Pamijahan, berdasarkan studi pendahuluan yang telah di lakukan sudah terlihat optimal, tetapi masih di temukan beberapa guru yang berkemampuan pedagogiknya menunjukan keadaan yang kurang sehingga berpengaruh terhadap hasil belajar. Padahal seperti yang kita ketahui guru terlihat dari rasa tanggung jawabnya ketika menjalankan amanah dan rasa tanggung jawab moral di pundaknya. Namun semua itu akan terlihat pada kepatuhan dan loyalitas dalam menjalankan tugas keguruannya didalam kelas.

Penelitian ini untuk mengetahui hubungan antara persepsi siswa tentang kemampuan pedagogik guru dengan hasil belajar mata pelajaran IPS kelas VIII di SMP Al-Amin Pamijahan Bogor.

\section{TINJAUAN PUSTAKA}

Hasil belajar adalah sebuah kalimat yang terdiri dari dua kata yaitu hasil dan belajar. Antara kata hasil dan belajar mempunyai dua arti yang berbeda oleh karena itu, sebelum pengertian hasil belajar, ada baiknya pembahasan ini diarahkan pada masingmasing permasalahan terlebih dahulu untuk mendapatkan pemahaman lebih jauh mengenai makna kata hasil dan belajar. Hal ini juga untuk memudahkan dalam memahami lebih mendalam tentang pengertian hasil belajar itu sendiri. ${ }^{1}$

Belajar ialah suatu kata yang sudah akrab dengan semua lapisan masyrakat. Bagi para pelajar atau mahasisawa kata belajar merupakan kata yang tak asing. Bahkan sudah merupakan bagian yang tidak dipisahkan dari semua kegiatan mereka dalam menuntut ilmu dilembaga pendidikan formal. Kegiatan belajar mereka lakukan setiap waktu

1. Slameto,2010. Belajar dan faktor-faktor yang mempengaruhi (cet. 5.jakarta : PT Rineka Cipta 
sesuai keinginan. Masalah pengertian belajar ini, para ahli psikologi dan pendidikan mengemukakan rumusan yang berlainan sesuai dengan bidang keahlian mereka masingmasing. Tentu saja mereka mempunyai alasan yang dapat dipertanggungjawabkan secara ilmiah.

Menurut pengertian secara psikologis, belajar merupakan suatu proses perubahan yaitu perubahan tingkah laku sebagai hasil dari interaksi dengan lingkungannya dalam memenuhi kebutuhan hidupnya. Belajar adalah suatu proses perubahan tingkah laku ini tidak hanya meliputi perubahan dalam kognitif atau pengetahuan saja, tetapi juga meliputi sikap (efektif) dan psikomotorik. ${ }^{2}$

Belajar adalah perubahan disposisi atau kemampuan yang dicapai seseorang melalui aktivitas yang di peroleh langsung dari proses pertumbuhan seseorang secara alamiah. ${ }^{3}$ Belajar sebagai konsep mendapatkan pengetahuan dalam prakteknya banyak dianut. Guru bertindak sebagai pengajar yang berusaha memberikan ilmu pengetahuan sebanyak-banyaknya dan peserta didik giat mengumpulkan dan menerimanya.

Belajar adalah proses perubahan perilaku berkat pengalaman dan latihan. ${ }^{4}$ Prof. Dr. H. Engkoswara menjelaskan belajar adalah proses perubahan prilaku yang dinyatakan dalam bentuk penugasan, penggunaan, dan penilaian tentang pengetahuan, sikap, nilai dan keterampilan. ${ }^{5}$ Belajar ialah suatu proses usaha yang dilakukan seseorang untuk memperoleh suatu perubahan tingkah laku yang baru secara keseluruhan, sebagai hasil pengalamannya sendiri dalam interaksi dan lingkungannya. Artinya adalah perubahan tingkah laku, baik yang menyangkut pengetahuan, keterampilan maupun sikap, bahkan meliputi segenap aspek organisme atau pribadi. Kegiatan belajar mengajar seperti mengorganisasi pengalaman belajar, mengolah kegiatan belajar mengajar, menilai proses, dan hasil belajar. Semua itu termasuk dalam cakupan tanggung jawab guru. Jadi hakikat belajar adalah perubahan.

Belajar ialah suatu proses usaha yang dilakukan seseorang untuk memperoleh suatu perubahan tingkah laku yang baru secara keseluruhan, sebagai hasil

\footnotetext{
${ }^{2}$ Tim dosen MKDK 1996.kurikulum dan pembelajaran.( Cet 1.Bandung : teknologi pendidikan ).h.35

${ }^{3}$ Agus Suprijono, 2009. Cooperative Learning Teori \& Aplikasi PAIKEM (Cet. 1. Yogyakarta : Pustaka Pelajar). h. 2

${ }^{4}$ Syaiful Bahri Djamarah, 2006. Strategi Belajar Mengajar, ( cet. 3. Jakarta: Rineka Cipta). h. 10

${ }^{5}$ Sudirman N, 1991, Ilmu Pendidikan, (Cet.4.Bandung : Remaja Rosdakarya).hal.99
} 
pengalamannya sendiri dalam interaksi dan lingkungannya. ${ }^{6}$ Dengan berakhirnya suatu proses belajar maka siswa memperoleh hasil belajar. Dimyati dan Mudjiono juga menyebutkan hasil belajar merupakan hasil dari suatu interaksi tindak belajar dan tindak mengajar. ${ }^{7}$

Dari sisi guru, tindak mengajar diakhiri dengan proses evaluasi hasil belajar. Dari sisi siswa, hasil belajar merupakan berakhirnya penggal dan puncak proses belajar. Hasil belajar untuk sebagian adalah berkat tindak guru, suatu pencapaian tujuan pengajaran. Pada bagian lain merupakan peningkatan kemampuan mental siswa. ${ }^{8}$ Begitupun menurut Hamalik bahwa hasil belajar adalah perubahan tingkah laku pada diri siswa, yang dapat diamati dan diukur dalam bentuk perubahan pengetahuan, sikap dan keterampilan. ${ }^{9}$ Siswa adalah subjek yang terlibat dalam kegiatan belajar mengajar disekolah. Dalam kegiatan tersebut siswa mengalami tindak mengajar, dan merespon dengan tindak belajar. Pada umumnya semula siswa belum menyadari pentingnya belajar. Berkat informasi guru tentang sasaran belajar, maka siswa mengetahui arti belajar bahan belajar baginya.

Perubahan tersebut dapat diartikan terjadinya peningkatan dan pengembangan yang lebih baik dibandingkan dengan sebelumnya, misalnya dari tidak tahu menjadi tahu, sikap kurang sopan menjadi sopan dan sebagainya, hasil belajar itu biasanya dinyatakan dalam bentuk perubahan pengetahuan, sikap dan keterampilan. Adapun faktor-faktor yang mempengaruhi hasil belajar Menurut Rusman ada dua macam ${ }^{10}$ yaitu:

Faktor intern adalah faktor-faktor yang berasal dari dalam diri seseorang yang dapat mempengaruhi prestasi belajarnya. Diantara faktor-faktor intern yang dapat mempengaruhi prestasi belajar seseorang antara lain: 1) Kecerdasan/intelegensi 2) Bakat 3) Minat 4) Motivasi.

Faktor ekstern adalah faktor-faktor yang dapat mempengaruhi prestasi belajar seseorang yang sifatnya berasal dari luar diri seseorang tersebut. Yang termasuk faktorfaktor ekstern antara lain:

1. Keadaan lingkungan keluarga

\footnotetext{
${ }^{6}$ Ibid ,.h, 102.

${ }^{7}$ Dimyati, 2013. Belajar \& Pembelajaran, (cet. 5. Jakarta : Rineka Cipta). h. 3

${ }^{8}$ Ibid., h. 10

${ }^{9}$ Hamalik, 2011, kurikulum dan pembelajaran . (Cet.4. Jakarta : Bumi Aksara). h. 155

${ }^{10}$ Sudirman, Op. Cit., h. 54
} 
2. Keadaan lingkungan sekolah

3. Keadaan lingkungan masyarakat

Kedua faktor diatas mempunyai hubungan berbanding lurus dengan hasil belajar peserta didik. Artinya makin tinggi kemampuan peserta didik dan kualitas pengajaran, makin tinggi pula hasil belajar peserta didik.

Berdasarkan penjabaran di atas dapat dipahami bahwa, hasil belajar adalah kemampuan-kemampuan yang dimiliki siswa setelah menerima pengalaman belajarnya. Kemampuan-kemampuan tersebut mencakup aspek kognitif, afektif, dan psikomotorik. Hasil belajar dapat dilihat melalui kegiatan evaluasi yang bertujuan untuk mendapatkan data pembuktian yang akan menunjukkan tingkat kemampuan siswa dalam mencapai tujuan pembelajaran.

Ilmu Pengetahuan Sosial (IPS) merupakan integrasi dari berbagai cabang ilmu sosial, seperti sosiologi, sejarah, geografi, ekonomi, politik, hukum, dan budaya. Ilmu pengetahuan sosial dirumuskan atas dasar realitas dan fenomena sosial yang mewujudkan satu pendekatan interdisipliner dari aspek cabang-cabang ilmu-ilmu sosial. IPS atau studi sosial merupakan bagian kurikulum sekolah yang di turunkan dari isi materi cabng-cabang ilmu-ilmu sosial.( sosiologi, sejarah, geografi, ekonomi, politik, hukum, dan budaya). IPS atau studi sosial merupakan bagian dari kurikulum sekolah yang diturunkan dari isi materi cabang-cabang ilmu sosial: sosiologi, sejarah, geografi, ekonomi, politik, antropologi, filsafat, dan fisikologi sosial.

Geografi, sejarah, dan Antropologi merupakan disiplin ilmu yang memiliki keterpaduan yang tinggi. Pembelajaran Geografi memberikan kebuletan wawasan yang berkenaan dengan wilayah-wilayah. Sedangkan sejarah memberikan wawasan berkenaan dengan peristiwa-peritiwa dari berbagai periode, Antropolgi meliputi studistudi komparatif yang berkenaan dengan nilai-nilai kepercayaan, stuktur sosial oranisasi politik, spiritual, teknologi dan benda benda budaya dari budaya- budaya terpilih. ${ }^{11}$

Ilmu Pengetahuan Sosial (IPS), itu membahas hubungan antara manusia dengan lingkungannya. Lingkungan masyarakat dimana anak didik tumbuh dan berkembang sebagai bagian dari masyarakat, dihadapkan pada berbagai permasalahan yang ada dan terjadi dilingkungan sekitar. ${ }^{12}$

${ }^{11}$ Trianto, 2012. Model pembelajaran terpadu ( Cet IV. Jakarta : Bumi aksara ), h.46.

${ }^{12}$ Ibid. h.172. 
Tujuan dari pendidikan IPS adalah untuk mendidik dan memberi bekal kemampuan dasar pada siswa untuk mengembangkan diri sesuai dengan bakat, minat, kemampuan, dan lingkungannya, serta berbagai bekal siswa untuk melanjutkan pendidikan kejenjang yang lebih tinggi. Sedangkan tujuan utama Ilmu Pengetahuan Ilmu Sosial ialah untuk mengembangkan peserta didik agar peka terhadap masalah sosial yang terjadi dimasyarakat, memiliki sikap mental positif terhadap perbaikan segala ketimpangan yang terjadi, dan terampil mengatasi setiap masalah yang terjadi sehari-hari baik yang menimpa dirinya sendiri maupun yang menimpa masyarakat. Tujuan tersebut dapat dicapai manakal program-program pembelajaran IPS disekolah di organisasikan secara baik.

Awan Mutakin dalam puskur, tujuan tersebut dapat dirinci sebagai berikut:

1. Memiliki kesadaran dan kepedulian terhadap masyarakat atau lingkungan.

2. Mengetahui dan memahami konsep dasar dan mampu mengunakan metode yang diadaptasi dari ilmu-ilmu sosial.

3. Mampu menggunakan model-model dan proses berfikir serta membuat keputusan untuk menyelesaikan isu dan masalah yang berkembang di masyarakat.

4. Menaruh perhatian terhadap isu-isu dan masalah-masalah sosial, serta mampu membuat analisis yang kritis, selanjutnya mampu mengambil tindakan yang tepat.

5. Mampu mengembangkan berbagai potensi sehingga mampu membangun diri sendiri agar survive yang kemudian bertanggung jawab membangun masyarakat.

6. Memotifasi seseorang untuk bertindak berdasarkan moral.

7. Faisilitator di dalam suatu lingkungan yang terbuka dan tidak bersifat menghakimi. ${ }^{13}$

Istilah pendidikan IPS dalam menyelenggarakan pendidikan di indonesia masih relatif baru digunakan. Pendidikan IPS merupakan padanan dari sosial studies dalam konteks kurikulum di Amerika Serikat. Istilah tersebut pertama kali digunakan di AS pada tahun 1913 mengadopsi nama lembaga sosial studies yang mengembangkan kurikulum di AS Marsh, dan Martoela. ${ }^{14}$

Standar kompetensi dan kompotensi dasar IPS juga menyangkut berbagai masalah sosial yang dirumuskan dengan pendekatan interdisipliner dan multidisipliner. Standar

${ }^{13}$ Ibid .,h. 174.

${ }^{14}$ Ibid., h. 171. 
kompetensi dan kompotensi dasar dapat menyangkut peristiwa dan perubahan kehidupan dengan prinsip.

Ilmu Pengetahuan Sosial (IPS) pada awalnya berasal dari literatur pendidikan Amerika Serikat dengan nama Social Studies. Ilmu Pengetahuan Sosial merupakan mata pelajaran yang di dalamnya mengkaji seperangkat peristiwa, fakta, konsep, dan generalisasi yang berkaitan dengan isu sosial dan kewarganegaraan. Lebih spesifik lagi dijelaskan bahwa ilmu Pengetahuan Sosial merupakan mata pelajaran yang berdiri sendiri sebagai integrasi dari sejumlah konsep disiplin ilmu sosial, humaniora, sains bahkan isu dan masalah sosial lainnya. ${ }^{15}$

Ilmu Pengetahuan Sosial harus mencerminkan sifat interdisipliner. Sifat interdisipliner dapat dilakukan dengan membekali siswa pengetahuan sosial yang berguna dalam kehidupan masyarakat, membekali kemampuan mengidentifikasi, menganalisis, dan menyusun alternatif pemecahan masalah sosial yang terjadi dalam kehidupan masyarat. Selanjutnya, Ilmu Pengetahuan Sosial diharapkan mampu membekali siswa kemampuan berkomunikasi antar sesama, membekali siswa dengan kesadaran, sikap mental positif dan keterampilan terhadap lingkungan hidup serta membekali siswa dengan kemampuan mengembangkan pengetahuan dan keilmuan sesuai dengan perkembangan ilmu dan teknologi.

Hasil Belajar adalah perubahan perilaku pada diri pembelajar setelah mengalami proses. ${ }^{16}$ Berdasarkan pemenggalan katanya, "hasil" adalah sesuatu yang diusahakan, diperoleh, dibuat, dijadikan, dan sebagainya oleh usaha, pikiran, dan akibat. Sedangkan "belajar" adalah usaha yang dilakukan untuk memperoleh ilmu pengetahuan; berubahnya tingkah laku atau tanggapan yang disebabkan oleh pengalaman.Pendapat lain juga dijelaskan bahwa belajar merupakan sebuah proses sehingga hasil belajar dapat didefinisikan sebagai hasil yang diperoleh seseorang dari proses belajar ${ }^{17}$

Menurut Haryanto hasil belajar IPS merupakan hasil dari suatu interaksi tindak belajar dan tindak mengajar. Tindak mengajar adalah serangkaian aktivitas

${ }^{15}$ Ibid . h.47.

${ }^{16}$ Suyono, 2013. Belajar danpembelajaran ( Cet .V bandung : PT Remaja Rosdakarya), h. 49.

${ }^{17}$ Ibid ., h.53. 
guru dalam mengajar dengan diakhiri proses evaluasi hasil belajar. Sedangkan tindak belajar merupakan berakhirnya proses belajar ${ }^{18}$

Hasil belajar IPS merupakan hasil optimal siswa baik dalam aspek kognitif, afektif, ataupun psikomotorik yang diperoleh siswa setelah memperlajari IPS dengan jalan mencari berbagai informasi yang dibutuhkan baik berupa perubahan tingkah laku, pengetahuan, maupun keterampilan sehingga siswa tersebut mampu mencapai hasil maksimal belajarnya sekaligus memecahkan masalah yang berkaitan dengan masalah sosial dan menerapkannya dalam kehidupan masyarakat ${ }^{19}$

Berdasarkan pengertian di atas maka dapat disampaikan bahwa Hasil Belajar IPS adalah suatu penilaian akhir dari proses belajar mengajar dan pengenalan yang telah dilakukan berulang- ulang, untuk mencapai hasil yang optimal baik dalam aspek kognitif,efektif, ataupun psiomotorik.

Siswa adalah salah satu komponen manusiawi yang menempati posisi sentral dalam proses belajar mengajar. Menurut Kamus Besar Bahasa Indonesia siswa adalah murid (terutama pada tingkat sekolah dasar dan menengah). ${ }^{20}$ Di dalam proses belajar mengajar, siswa sebagai pihak yang ingin meraih cita-cita, memiliki tujuan dan kemudian ingin mencapainya secara optimal. Siswa atau anak didik itu akan menjadi faktor penentu, sehingga menuntut dan dapat mempengaruhi segala sesuatu yang diperlukan untuk mencapai tujuan belajarnya. Jadi dalam proses belajar mengajar yang diperhatikan pertama kali adalah siswa atau anak didik (anak berkonotasi dengan tujuan, karena anak didiklah yang memiliki tujuan), bagaimana keadaan dan kemampuannya. Bagaimana cara yang tepat untuk bertindak, alat dan fasilitass apa yang cocok dan mendukung, semua itu harus disesuaikan dengan keadaan atau karakteristik siswa. Memahami pengertian siswa atau peserta didik setidaknya bisa diselami dari tiga perspektif. Pertama, Perspektif, Pedagogis, Perspektif ini memandang peserta didik sebagai mahluk 'homo educantum' atau disebut dengan mahluk yang menghajatkan pendidikan. Dalam pengertian ini, peserta didik dipandang sebagai manusia yang memiliki potensi yang bersifat laten, sehingga dibutuhkan binaan dan bimbingan untuk

${ }^{18}$ Ibid ., h.59.

${ }^{19}$ Ibid ., h. 64.

${ }^{20}$ Tim Penyusun Kamus Pusat Bahasa, 2002. Kamus Besar Bahasa Indonesia, (cet. 3. Jakarta : Balai Pustaka,). h. 664. 
mengaktualisasikan segala potensi yang dimilikinya agar ia dapat menjadi manusia yang utuh.

Didalam kamus bahasa Indonesia berasal dari kata Mampu berarti kuasa (bisa, sanggup) melakukan sesuatu, berarti kaya mempunyai harta berlebih, kemampuan kesanggupan. Seorang dikatakan mampu apabila ia bisa atau tahu sanggup melakukan sesuatu yang ia lakukan. Kemampuan adalah kapasitas seseorang individu untuk melakukan beragam tugas dalam pekerjaan. ${ }^{21}$

Kemampuan sama dengan kompetensi, kompetensi berasal dari bahasa inggris yaitu competence maknanya sama dengan being competent, sedangkan competent sama dengan having ability, power authority, skill,knowledge attitude,dan sebagainya. Dengan demikian kompetensi adalah kemampuan, kecakapan, keterampilan, dan pengetahuan seseorang di bidang tertentu. Jadi kompetensi diartikan sebagai kecakapan yang memadai untuk melakukan sesuatu tugas atau suatu keterampilan dan kecakapan yang disyaratkan. ${ }^{22}$

Istilah pedagogik ( bahasa belanda ) harus diterjemahkan dengan kata ilmu mendidik atau ilmu tentang pendidikan, isi pengertiannya ialah suatu uraian atau bahasa materi atau teori mengenai apakah mendidik itu. Sedangkan pengertian ilmu mengandung arti bahwa segala permasalahan yang harus mencangkup dan dibicarakan telah masuk atau dibahas didalamnya, telah disusun secara teratur dan sistematis serta lengkap sehingga tidak ada satu aspek bahasan atau masalah yang terlewat, tercecer, atau tidak dibahas. ${ }^{23}$

Pedagogik adalah suatu kegiatan atau keaktifan yang sedang dilakukan yang berupa tindakan pendidikan seperti menasehati, menegur, memberikan contoh yang bertujuan untuk mencapai tujuan pendidikan tertentu. Pedagogik adalah suatu ilmu yang bukan saja menalaah objeknya untuk mengetahui betapa keadaan atau hakiki objek itu, melainkan mempelajari pula betapa hendaknya bertindak. ${ }^{24}$

Secara pedagogis kemampuan guru-guru dalam mengelola pembelajaran perlu mendapat perhatian yang serius. Hal ini penting karena pendidikan di Indonesia

\footnotetext{
${ }^{21}$ Miyam yusdi.2012,seluk beluk profesi guru( cet .III Jakarta : Pt Pribumi mekar),h. 67

${ }^{22}$ Asep Hendry Hermawan, 2010. Pengembangan kurikulum dan pembelajran (cet .14 Jakarta : Universitas terbuka), h.79

${ }^{23}$ Jusup djajadisastra. 1991. Pedagogik ilmu mendidik teoritis ( Cet.1. bandung : cv handayani ), h.5

${ }^{24}$ Sri Awan Sari.2011. Bahan ajar pendidikan dan pembelajaran ( Cet .1. Jakarta : STKIP kusuma Negara ) h.13.
} 
dinyatakan kurang berhasil oleh sebagian masyarakat, dinilai kering dari aspek pedagogis,dan sekolah nampak lebih mekanis sehingga peserta didik cenderung kerdil karena tidak mempunyai dunia sendiri.

Guru adalah pendidik professional dengan tugas utama mendidik, mengajar, membimbing mengarahkan, melatih, menilai dan mengevaluasi peserta didik. ${ }^{25}$ Guru di harapkan membimbing dan mengarahkan pengembangan kurikulum dalam pembelajaran secara efektif, serta melakukan pengawasan dalam pelaksanaannya. Dalam proses pengembangan program, guru hendaknya tidak membatasi diri pada pembelajaran dalam arti sempit, tetapi harus menghubungkan program program pembelajaran dengan seluruh kehidupan peserta didik kebutuhan masyrakat dan dunia usaha. Guru juga harus berpacu dalam pembelajaran dalam memberikan kemudahan dalam belajar bagi seluruh peserta didik agar mengembangkan potensinya secara optimal. Dalam hal ini guru harus kreatif, professional, dan menyenangkan dengan memposisikan sebagai berikut :

Majid menjelaskan kemampuan yang dimiliki oleh setiap guru akan menunjukan kualitas guru dalam mengajar. Kemampuan tersebut akan terwujud dalam bentuk penguasaan, pengetahuan dan professional dalam menjalakan fungsinya sebagai guru. ${ }^{26}$ Kemampuan disisi lain, merupakan tugas khusus yang berarti hanya dapat dilakukan oleh orang-orang spesial/tertentu. Artinya tidak sembarang orang dapat melakukan tugas tersebut. Sedangkan yang dimaksud dengan pedagogik adalah suatu uraian atau bahasa materi atau teori mengenai kegiatan atau keaktifan yang sedang dilakukan yang berupa tindakan pendidikan

Dari penjelasan tersebut, dapat disampaikan yang dimaksud dengan persepsi siswa tentang kemampuan pedagogik guru adalah merupakan suatu tanggapan terhadap objek yang diterima melalui proses, mengamati, memilih, mengorganisasikan, menyimpulkan atau menginterprestasikan.

\section{Metode Penelitian.}

Metode yang digunakan dalam Penelitian ini adalah metode Penelitian kuantitatif dengan menggunakan Pendekatan korelasional. Penelitian kuantitatif, adalah

\footnotetext{
${ }^{25}$ Republik Indonesia, 2006.undang-undang tentang guru dan dosen ( pada BABI ketentuan Umum pasalI) Jakarta : CV EKa Jaya, h.4.

${ }^{26}$ Ibid .,h. 29
} 
Penelitian dengan memperoleh data yang berbentuk angka atau data kualitatif yang di angkakan. Sedangkan pendekatan penelitian korelasional adalah suatu penelitian yang melibatkan pengumpulan data untuk menentukan apakah terdapat hubungan antara dua variabel atau lebih. Bentuk hubungan dalam penelitian ini adalah Brivaret, yaitu hubungan yang melibatkan satu variabel bebas dengan satu variabel terikat, penelitian korelasional melibatkan pengumpulan data untuk menentukan apakah terdapat hubungan antara dua atau lebih variabel serta seberapa besar tingkatan hubungan tersebut. Tingkatan hubungan diungkapkan sebagai suatu koefisien korelasi. ${ }^{27}$

Teknik ini digunakan untuk mencari korelasi hubungan persepsi siswa tentang kemampuan pedagogik guru dengan hasil belajar mata pelajaran IPS kelas VIII di SMP Al-Amin Pamijahan Bogor.

\section{ANALISIS DATA DAN PEMBAHASAN}

Data Tentang Persepsi Siswa Tentang Kemampuan Pedagogik Guru Mata Pelajaran IPS (X). Untuk menentukan nilai kuantitatif persepsi siswa tentang kemampuan pedagogik guru studi pada mata pelajaran IPS dengan menjumlahkan skor jawaban angket dari responden.

Dari data skor perhitungan persepsi siswa tentang kemampuan pedagogik di atas yang terdiri dari 60 siswa sebagai sampel diperoleh skor terendah sebesar 32 dengan skor tertinggi 93, range skor 62, skor rata-rata (mean ) sebesar 66,6 median sebesar 67,5, dan modus sebesar 68,49, sedangkan besar simpangan baku 2,59.

Berdasarkan data maka persepsi siswa tentang kemampuan pedagogik guru memiliki nilai antara 68 -76. Untuk mengetahui kecendrungan persepsi siswa tentang kemapuan pedagogik guru secara keseluruhan dapat diketahui melalui perhitungan persentase frekuensi dengan perhitungan rumus perhitungan persentase. Dari hasil perhitungan menunjukan bahwa persepsi siswa tentang kemampuan pedagogik guru sangat tinggi sebesar $6,66 \%$ berkriteria tinggi sebesar $8,33 \%$ berkriteria sedang sebesar $66,66 \%$ berkriteria rendah $15 \%$ dan berkriteria sangat rendah 3,33\%.

Data Hasil Belajar SMP Al-Amin Pamijahan Bogor (Y). Untuk mendapatkan data penelitian tentang hasil belajar mata pelajaran IPS kelas VIII peneliti mengambil nilai dari hasil belajar MID semester ganjil tahun ini. 2010), h. 37

${ }^{27}$ Emzir, Metodologi Penelitian Pendidikan Kuantitatif \& Kualitatif, (Jakarta: Rajawali pres, 
Dari data skor perhitungan hasil belajar mata pelajaran IPS di atas yang terdiri dari 60 siswa sebagai sampel diperoleh skor terendah sebesar 61 dengan skor tertinggi 95, range skor 35, skor rata-rata (mean ) sebesar 80,25 median sebesar 89,5, dan modus sebesar 86,75, sedangkan besar simpangan baku 4,54.

Berdasarkan data dapat dilihat bahwa banyaknya hasil belajar mata pelajaran IPS memiliki nilai antara 76 - 80 dan 86 - 90. Untuk mengetahui kecenderungan hasil belajar tersebut keseluruhan dapat diketahui melalui perhitungan persentase frekuensi yaitu $=28,33 \%$ (sedang ) , 41,66\% ( tinggi ), $30 \%$ ( sangat tinggi ). Dengan rentangan 0 - 95 hasil perhitungan menunjukan bahwa hasil belajar mata pelajaran IPS sedang sebesar $28,33 \%$ berkriteria tinggi sebesar $41,66 \%$ dan berkriteria sangat tinggi $30 \%$

Data yang telah terkumpul kemudian peneliti olah mengetahui hubungan persepsi siswa tentang kemampuan pedagogik guru dengan hasil belajar mata pelajaran IPS kelas VIII. Maka dilakukan perhitungan korelasi product moment, dengan hasil 0,57

Selanjutnya untuk menyatakan besar kecilnya sumbangan variabel $\mathrm{X}$ terhadap $\mathrm{Y}$ dapat ditentukan dengan rumus koefisien diterminan didapat hasil sebagai berikut berikut $32,49 \%$. Artinya hubungan persepsi siswa tentang kemampuan pedagogik guru $32,49 \%$ dan sisanya $67,51 \%$ ditentukan oleh variabel lain atau variasi yang terjadi dengan hasil belajar. Secara nyata hasil belajar 32,49\% di pengaruhi oleh persepsi siswa tentang kemampuan pedagogik guru.

Untuk menguji keberatiannya sebelum di tafsirkan, maka terlebih dahulu dilakukan uji t pada taraf signifikan yaitu didapat hasil 5,38. t tabel pada taraf signifikan 0,05 dengan $\mathrm{dk}=\mathrm{N}-2=60-2=58$ adalah 2,000. Dari hasil perhitungan diperoleh $\mathrm{t}$ hitung 5,38 sedangkan $\mathrm{t}$ tabel 2,000. Yang berarti $\mathrm{t}$ hitung $(5,38)>\mathrm{t}$ tabel $(2,000)$ maka koefesien kolerasi adalah signifikan. Dengan demikian, terdapat hubungan positif antara persepsi siswa tentang kemampuan pedagogik guru dengan hasil belajar mata pelajaran IPS kelas VIII.

Interpretasi data yang disajikan berikut ini mengacu pada permasalahan yang telah dirumuskan. Masalah tersebut mempertanyakan apakah terdapat hubungan yang siginifikan antara persepsi siswa tentang kemampuan pedagogik guru dengan hasil belajar mata pelajaran IPS kelas VIII di SMP Al-amin pamijahan bogor. 
Hasil penelitian membuktikan bahwa persepsi siswa tentang kemampuan pedagogik guru di SMP Al-Amin Pamijahan Bogor memiliki kriteria sangat rendah 3,33 $\%$, rendah sebesar $15 \%$. berkriteria sedang sebesar 66,66\%,berkriteria tinggi sebesar $8,33 \%$, dan berkriteria sangat tinggi sebesar 6,66 \%, dilihat dari rata-rata sebesar 66,6 $\%$, yang termasuk kriteria sedang. Dengan demikian dapat disimpulkan bahwa persepsi siswa tentang kemampuan pedagogik guru SMP Al-Amin Pamijahan Bogor tergolong dalam kriteria sedang.

Berdasarkan hasil penelitian di atas, bahwa hasil belajar mata pelajaran IPS kelas VIII dalam kriteria sedang sebesar 28,33 \%, kriteria tinggi sebesar 41,66 \%, dan dalam kriteria sangat tinggi sebesar $30 \%$, dilihat dari rata-rata sebesar 80,25\%, yang termasuk kriteria tinggi. Dengan demikian dapat disimpulkan bahwa hasil belajar mata pelajaran IPS kelas VIII di SMP Al-Amin Pamijahan Bogor termasuk dalam kriteria tinggi.

Untuk menunjukan ada tidaknya hubungan persepsi siswa tentang kemampuan pedagogik guru dengan hasil belajar mata pelajaran IPS kelas VIII, maka dilakukan uji kolerasi product moment. Berdasarkan hasil pengujian $r_{x y}$ hitung sebesar 0,577 dan $r_{x y}$ tabel pada $\mathrm{N}=60$ dan taraf siginifikan $5 \%$ yang diperoleh 0,254 . Setelah itu dilanjutkan mengukur besar kecilnya sumbangan variabel $\mathrm{X}$ terhadap $\mathrm{Y}$ ditentukan dengan rumus

koefesien diterminan dengan hasil 32,49\%. Artinya hubungan persepsi siswa tentang kemampuan pedagogik guru $32,49 \%$ dan sisanya $67,51 \%$ ditentukan oleh variabel lain atau variasi yang terjadi terhadap hasil belajar.

Selanjutnya untuk menguji keberartiannya maka dilakukan uji t hitung. Berdasarkan hasil pengujian thitung sebesar 5,38 dan $\mathrm{t}$ tabel dengan derajat kebebasan $\mathrm{dk}=\mathrm{N}-2$ dan $\mathrm{a}=0,025$ sebesar 2,000. Hal ini berarti $\mathrm{t}$ hitung lebih besar dari t tabel (5,38> 2,000.). Hasil pengujian terhadap koefesien korelasi yang diperoleh dari hasil perhitungan bahwa $r_{x y} 0,577$ signifikan. Dengan demikiam $\mathrm{H}_{\mathrm{o}}$ di tolak sedangkan $\mathrm{H}_{\mathrm{a}}$ diterima yang berarti terdapat hubungan yang positif antara persepsi siswa tentang kemampuan pedagogik guru dengan hasil belajar mata pelajaran IPS kelas VIII di SMP Al-Amin Pamijahan Bogor. Hal tersebut terbukti dengan hasil nilai $r$ hitung lebih besar dari pada $r$ tabel.

Dari hasil perhitungan product moment di atas diketahui bahwa nilai $r_{\text {hitung adalah }}$ 0,577 sedangkan $r$ tabel adalah 0,254 dengan batas signifikan 5\% artinya nilai $r_{\text {hitung lebih }}$

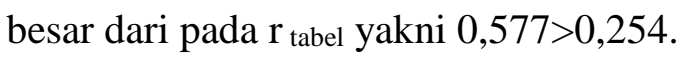


Dengan demikian nilai $r$ product moment terdapat hubungan antara persepsi siswa dengan kemampuan pedagogik guru dengan hasil belajar mata pelajaran IPS kelas VIII, dan $\mathrm{t}$ pada perhitungan taraf signifikan 0,025 dengan $\mathrm{dk}=\mathrm{N}-2=58$ juga terdapat pengaruh positif, terbukti t hitung $(5,38)$ lebih besar dari t tabel $(2,000)$, yakni 5,38> 2,000 yang berarti $\mathrm{H}_{0}$ ditolak sedangkan $\mathrm{H}_{\mathrm{a}}$ diterima..

Untuk menyatakan dan mementukan bobot tingkat hubungan persepsi siswa tentang kemampuan pedagogik guru dengan hasil belajar mata pelajaran IPS kelas VIII, penulis menggunakan kriteria dari buku Sugiono.

Berdasarkan kriteria tingkat kolerasi di atas, diketahui $r$ hitung adalah 0,577 yang berarti berada di antara 0,400 sampai 0,599 maka dapat dikatakan bahawa hubungan persepsi siswa tentang kemampuan pedagogik guru dengan hasil belajar mata pelajaran IPS kelas VIII di SMP Al-Amin Pamijahan Bogor mempunyai korelasi yang sedang karena persepsi siswa tentang kemampuan pedagogik guru akan berhubungan dengan hasil belajar.

\section{KESIMPULAN DAN SARAN}

\section{A. Simpulan}

Setelah peneliti melakukan penelitian dan menganalisis data yang telah diperoleh, baik yang besifat teoritis maupun lapangan tentang hubungan persepsi siswa tentang kemampuan pedagogik guru dengan hasil belajar mata pelajaran IPS kelas VIII di SMP Al-Amin pamijahan Bogor. Maka dapat disimpulkan sebagai berikut :

Persepsi siswa tentang kemampuan pedagogik guru di SMP Al-amin pamijahan bogor. Nilai rata-rata 66,6 , nilai tertinggi 93 , nilai terendah 32 , nilai diatas rata-rata $66,66 \%$, dan nilai dibawah rata-rata 33,34\%, dengan itu dapat disimpulkan bahwa persepsi siswa tentang kemampuan pedagogik guru memiliki kriteria tinggi

Hasil belajar mata pelajaran IPS kelas VIII di SMP Al-Amin Pamijahan Bogor. Nilai rata-rata 80,25 , nilai tertingi 95 , nilai terendah 61 , nilai diatas rata-rata $71,66 \%$, dan nilai dibawah rata-rata $28,34 \%$, dengan demikian hasil belajar mata pelajaran IPS kelas VIII memiliki kriteria tinggi.

Terdapat hubungan positif antara persepsi siswa tentang kemampuan pedagogik guru dengan hasil belajar mata pelajaran IPS kelas VIII di SMP Al-Amin Pamijahan Bogor. Hal ini dapat dibuktikan dengan derajat kebebasan $(\mathrm{DK})=-2$ dan $\mathrm{a}=0,025$ 
sebesar 2,000 thitung $(5,38)>\mathrm{t}$ tabel $(2,000)$ maka koefesien korelasi adalah signifikan, nilai $r$ hitung adalah 0,577 sedangkan $r$ tabel adalah 0,254 dengan batas signifikan $5 \%$

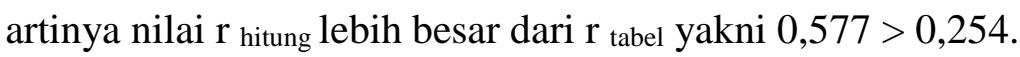

Dengan demikian dapat dikatakan bahwa terdapat hubungan yang positif antara persepsi siswa tentang kemampuan pedagogik guru dengan hasil belajar mata pelajaran IPS kelas VIII di SMP Al-Amin Pamijahan Bogor.

\section{B. Saran}

Didalam melakukan kegiatan belajar mengajar guru hendaknya berusaha untuk meningkatkan kemapuan pedagogiknya, sehingga dapat menimbulkan kenyamanan bagi siswa pada ssst kegiatan belajar mengajar.berlangsung.

Siswa merupakan subyek dalam proses belajar mengajar, hendaknya guru dapat mengerti dan mengetahui kondisi siswanya sehingga dapat menciptakan belajar yang kondusif.

Guru harus menciptakan sussana belajar mengajar yang menyenangkann dan tidak terlalu mengekang siswa sehingga akan menimbulkan persepsi baik / positif terhadap guru tersebut dan akan berdampak baik pula bagi hasil belajar siswa.

\section{Referensi}

Alsa, Asmadi 2003. Pendekatan Kuantitatif dan Kualitatif Serta Kombinasinya dalam Penelitian Psikologi. Yogyakarta: Pustaka Pelajar

Awan, Sri. 2011. Bahan Ajar Pendidikan Dan Pembelajaran. Jakarta : STKIKusuma Negara.

Arsyad, dan Sulfemi, Wahyu Bagja. (2014). Minat Siswa Tentang Keadministrasian dengan Hasil Belajar Administrasi Perkantoran. Edutecno. 9 (2), 40-50.

Badar, Dadan Samsul dan Sulfemi, Wahyu Bagja. (2014). Pengaruh Rasa Percaya Diri dan Motivasi Berprestasi Terhadap Kinerja di Kecamatan Ciampea Kabupaten Bogor. Edutecno. 10 (1), 1-10

Bahri, Djamarah Syaiful. 2006. Strategi Belajar Mengajar. Jakarta: Rineka Cipta.

Djajadisastra, Jusup.1991. Pedagogik Ilmu Mendidik Teoritis. Bandung : CV Handayani.

Dimyati, 2013. Belajar \& Pembelajaran. Jakarta : Rineka Cipta.

Emzir, 2010. Metodologi Penelitian Pendidikan Kuantitatif \& Kualitatif. Jakarta: Rajawali pres. 
Fajartriani, Tia dan Sulfemi, Wahyu Bagja. (2014).Pengaruh Motivasi Kerja Guru dan Iklim Organisasi Terhadap Kinerja Guru SMA Negeri di Kecamatan Cigudeg. Edutecno. 8 (1), 17-26

Hadjar, Ibnu. 1996. Dasar-Dasar Metodologi Penelitian Kuantitatif Dalam Pendidikan. Jakarta : Raja Grafindo persada.

Hamalik, 2011, Kurikulum dan Pembelajaran. Jakarta : Bumi Aksara

Hendry, Hermawan Asep. 2010. Pengembangan Kurikulumd dan Pembelajran. Jakarta : Universitas terbuka.

Karsiwan, Wawan dan Sulfemi, Wahyu Bagja. (2016). Hubungan Penerimaan Diri Dengan Kinerja Guru SD Di Kecamatan Pamijahan Kabupaten Bogor Edutecno. 15. (1). 1-10.

Mulyasa, E. 2013. Guru Menjadi Profesiaonal. Bandung : PT Remaja Rosda karya.

Mushaf, Jejen. 2001. Peningkatan Kompetensi Guru Melalui Pelatihan dan Sumber Belajar Teori Dan Praktik. Jakarta : Kharisma putra kencana.

Partanto, A.Pius. 1994. Kamus Ilmiah Popular. Surabaya, Arloka.

Purwanto, Metodologi Penelitian Kuantitatif Untuk Psikologi dan Pendidikan. Jakarta : Rineka cipta.

Republik Indonesia, 2006. Undang-Undang Tentang Guru dan Dosen pada BAB I ketentuan Umum pasal 1. Jakarta : CV EKa Jaya,

Slameto,2010. Belajar dan Faktor-Faktor yang Mempengaruhi. Jakarta : PT Rineka Cipta.

Sudirman N, 1991. Ilmu Pendidikan.Bandung : Remaja Rosdakarya

Suprijono,Agus. 2009. Cooperative Learning Teori \& Aplikasi PAIKEM. Yogyakarta : Pustaka Pelajar.

Sugiyono, 2013. Metode Penelitian Pendidikan Pendekatan Kuantitatif,Kualitatif, dan $R \& D .16$ Bandung : Alfabeta.

Suyono, 2013. Belajar dan Pembelajaran. Bandung : PT Remaja Rosdakarya

Tim Dosen MKDK 1996. Kurikulum dan Pembelajaran. Bandung : Teknologi Pendidikan.

Tim Penyusun Kamus Pusat Bahasa, 2002. Kamus Besar Bahasa Indonesia. Jakarta : Balai Pustaka.

Toha, Anggoro. 2000. Metodologi Penelitian Pendidikan. Jakarta: Rineka Cipta.

Trianto, 2012. Model Pembelajaran Terpadu. Jakarta : Bumi aksara.

Yusdi, Milyam. 2012. Seluk Beluk Profesi Guru. Jakarta : PT Pribumi mekar.

Sulfemi, Wahyu Bagja. (2013). Pengaruh Persepsi Siswa atas Kemampuan Pedagogik Guru dan Motivasi Belajar Siswa Terhadap Prestasi Belajar Ilmu Pengetahuan 
Sosial Siswa (Survei di SMK Swasta Kabupaten Bogor). Edutecno. 7 (2), 17 26.

Sulfemi, Wahyu Bagja. (2015). Pengaruh Metode Pembelajaran Kontekstual dan Penggunaan Media Video Pendidikan Terhadap Hasil Belajar IPS. Edutecno. $13(2), 1-10$.

Sulfemi, Wahyu Bagja. (2015). Kemampuan Pedagogik Guru. Prosiding Seminar Nasional. STKIP Muhammadiyah Bogor 1. (1). 71-83

Sulfemi, Wahyu Bagja. (2015). Challenges Of Indonesian Teacher Competence in dealing with Asean Economic Cummunity (AEC). Engglis Forum. 1 (1), 69-79

Sulfemi, Wahyu Bagja. (2016). Hubungan Persepsi Peserta Didik Tentang Kompetensi Guru Mata Pelajaran Sejarah dengan Hasil Belajar Mata Pelajaran Sejarah di Kelas X SMA Negeri 1 Pamijahan Kabupaten Bogor. Fascho, 5 (2), 52-70.

Sulfemi, Wahyu Bagja. (2016). Hubungan antara Persepsi Guru pada Kepemimpian Kepala Sekolah dan Motivasi Guru dengan Kinerja guru dalam Proses Pembelajaran di SMA Negeri 1 Ciomas. Fascho : Kajian Pendidikan dan Sosial Kemasyarakatan, 5 (1), 36-55.

Sulfemi, Wahyu Bagja. (2016). Kompetensi Profesionalisme Guru Indonesia dalam Menghadapi MEA. Prosiding Seminar Nasional STKIP Muhammadiyah Bogor. $1(1), 62-77$.

Sulfemi, Wahyu Bagja dan Lestari, Ayu Hopilatul. (2017). Korelasi Kompetensi Pedagogik Guru dengan Prestasi Belajar Mata Pelajaran IPS Di SMP Muhammadiyah Pamijahan Kabupaten Bogor. Edutecno. 16 (1), 1-16

Sulfemi, Wahyu Bagja. (2017). Analisis Pengaruh Motivasi Dan Disiplin Terhadap Kinerja Guru (Studi Kasus di SMA Negeri 1 Pamijahan Kabupaten Kabupaten Bogor). Prosiding Seminar Nasonal STKIP Muhammadiyah Bogor. 1 (1), 342357

Sulfemi, Wahyu Bagja dan Abdul Qodir. (2017). Hubungan Kurikulum 2013 Dengan Motivasi Belajar Peserta Didik Di SMK Pelita Ciampea. Edutecno 17 (2), 1-8

Sulfemi, Wahyu Bagja. (2018). Hubungan Motivasi Belajar Dengan Hasil Belajar IPS Di SMP Kabupaten Bogor. Edutecno 18 (2), 1-8.

Sulfemi, Wahyu Bagja dan Nurhasanah. (2018). Penggunaan Metode Demontrasi dan Media Audio Visual dalam Meningkatkan Hasil Belajar Peserta Didik Mata Pelajaran IPS. Jurnal Pendas Mahakam. 3 (2). 151-158.

Sulfemi, Wahyu Bagja dan Hilga Minati. (2018). Meningkatkan Hasil Belajar Peserta Didik Kelas 3 SD Menggunakan Model Picture And Picture dan Media Gambar Seri. JPSD. 4 (2), 228- 242.

Sulfemi, Wahyu Bagja. (2018). Pengaruh Disiplin Ibadah Sholat, Lingkungan Sekolah, dan Intelegensi Terhadap Hasil Belajar Peserta Didik Mata Pelajaran Pendidikan Agama Islam. Edukasi: Jurnal Penelitian Pendidikan Agama dan Keagamaan. 16 (2), 166-178. 
Widaryanto dan Wahyu Bagja Sulfemi. (2016). Korelasi Penguasaan TIK Guru dengan Kemampuan TIK Siswa. Edutecno. 14. (1). 1-10. 